\title{
Spatial representations in language and thought
}

\author{
Anna Papafragou \\ Department of Psychology, University of Delaware, USA \\ https://doi.org/10.36505/ExLing-2006/01/0006/000006
}

\begin{abstract}
The linguistic expression of space draws from and is constrained by basic, probably universal, elements of perceptual/cognitive structure. Nevertheless, there are considerable cross-linguistic differences in how these fundamental space concepts are segmented and packaged into sentences. This cross-linguistic variation has led to the question whether the language one speaks could affect the way one thinks about space - hence whether speakers of different languages differ in the way they see the world. This chapter addresses this question through a series of cross-linguistic experiments comparing the linguistic and non-linguistic representation of motion and space in both adults and children. Taken together, the experiments reveal remarkable similarities in the way space is perceived, remembered and categorized despite differences in how spatial scenes are encoded cross-linguistically.
\end{abstract}

\section{Introduction}

The linguistic expression of space draws from and is constrained by basic, probably universal, elements of perceptual/cognitive spatial structure. As is well known, the representation of space is a fundamental human cognitive ability (Pick \& Acredolo 1983; Stiles-Davis, Kritchevsky \& Bellugi 1988; Emmorey \& Reilly 1995; Hayward \& Tarr 1995; Newcombe \& Huttenlocher 2003; Carlson \& van der Zee 2005), and appears early in life (Pulverman, Sootsman, Golinkoff \& Hirsh-Pasek 2003; Casasola, Cohen \& Chiarello 2003; Casasola \& Cohen 2002; Quinn 1994; Pruden, Hirsh-Pasek, Maguire, Meyers \& Golinkoff 2004).

Nevertheless, there are considerable cross-linguistic differences in how these fundamental space components are segmented and packaged into sentences. This cross-linguistic variation has led to the question whether the way space is encoded cross- linguistically affects the way space is perceived, categorized and remembered by people who speak different languages (Bowerman \& Levinson, 2001; cf. Whorf, 1956). The goal of this paper is to address this question focusing on two strands of empirical work.

\section{Motion events}

The first set of studies we will review focus on a comparison of the linguistic and nonlinguistic representation of motion in speakers of English and Greek. These two languages differ in the way they encode the trajectory, or path,

ExLing 2006: Proceedings of 1st Tutorial and Research Workshop on Experimental Linguistics, 28-30 August 2006, Athens, Greece 
and the manner of motion (cf. Talmy, 1985): English includes a large class of manner of motion verbs (strut, stroll, sashay, etc.) which can be freely combined with adverbs, particles or prepositional phrases encoding trajectory information (away, into the forest, upwards, etc.). By contrast, Greek mostly expresses motion information in path verbs (beno 'enter', vjeno 'exit', perno 'cross', pao 'go', etc.) combined with prepositional phrases or adverbials which further specify path (sto spiti 'into the house', makria 'away', etc.). Greek does have a substantial inventory of manner verbs (xorevo 'dance', trexo 'run', pleo 'float', etc) but their distribution is constrained by what we will call a 'boundedness constraint': most manner verbs cannot combine with a modifier which denotes a bounded, completed path (*To puli petakse sto kluvi) unlike their English counterparts (The bird flew into the cage). This constraint leads to higher use of path verbs in Greek compared to English. A similar constraint is found in several languages (Aske 1989; Jackendoff 1990; Slobin \& Hoiting 1994; Levin \& Rapoport 1988) and has led commentators to conclude that manner of motion is less salient as a verb grammaticalization feature in languages such as Greek.

In our own work (Papafragou, Massey \& Gleitman 2002, 2006), we have confirmed the Manner/ Path asymmetry in the description of motion scenes by Greek- versus English-speaking children and, much more strongly, for Greek versus English-speaking adults. The very same studies, however, revealed no differences in the English- and Greek- speaking subjects' memory of path or manner details of motion scenes. Further experiments showed that, despite the asymmetry in verbally encoding motion events, English and Greek speakers did not differ from each other in terms of motion event categorization. More recent studies compared on-line inspection of motion events by Greek- and English-speaking adults using eye-tracking methodology (Papafragou, Hulbert \& Trueswell, 2006). Taken together, the experiments reveal remarkable similarities in the way motion is perceived, remembered and categorized despite differences in how motion scenes are encoded cross-linguistically.

\section{Spatial frames of reference}

The second set of experiments focuses on the linguistic description of location and orientation (Li, Abarbanell \& Papafragou, 2006). We study the spatial abilities of speakers of Tseltal, a Mayan language which lacks projective terms for left and right. Unlike English or other familiar languages, Tseltal speakers use absolute terms equivalent to north/south/east/west to locate objects in small-scale space (Levinson, 1996). As a result of this gap in linguistic resources, Tseltal speakers have been claimed not to use left-right distinctions in their habitual reasoning about 
space (Pederson, Danziger, Wilkins, Levinson, Kita, \& Senft, 1998; but see Li \& Gleitman, 2002 for critical discussion).

Our experiments test the use of left/right concepts in Tseltal speakers and compare them to absolute systems of spatial location and orientation ( $\mathrm{Li}$ et al., 2006). We find that Tseltal speakers, when given implicit cues that bodycentered (left-right) distinctions are needed to solve a spatial task, use these distinctions without problems. On certain tasks, performance with such body-centered distinctions is better than performance with absolute systems of orientation which correspond more closely to the preferred linguistic systems of encoding space in Tseltal. These results argue against the claim that left-right distinctions are dispreferred or less salient in Tseltal spatial cognition. We take this as another demonstration of the independence of spatial reasoning from linguistic (encoding) preferences. We conclude that the linguistic and non-linguistic representations of space, even though correlated, are distinct and dissociable.

\section{References}

Aske, J. 1989. Path predicates in English and Spanish: A closer look. Proceedings of the 15th Annual Meeting of the Berkeley Linguistics Society, 1-14. Berkeley, CA: BLS.

Bowerman, M. and Levinson, S., eds. 2001. Language acquisition and conceptual development. Cambridge: Cambridge University Press.

Carlson, L. and van der Zee, E., eds. 2005. Functional features in language and space: Insights from perception, categorization and development. Oxford: Oxford University Press.

Casasola, M. and Cohen, L. 2002. Infant spatial categorization of containment, support or tight fit spatial relations. Developmental Science, 5, 247-264.

Casasola, M., Cohen, L.B. and Chiarello, E. 2003. Six-month-old infants' categorization of containment spatial relations. Child Development, 74, 679693.

Choi, S., and Bowerman, M. 1991. Learning to express motion events in English and Korean: The influence of language-specific lexicalization patterns. Cognition, 41, 83-122.

Emmorey, K., and Reilly, J., eds. 1995. Language, gesture and space. Hillsdale, NJ: Erlbaum.

Hayward, W.G. and Tarr, M.J. 1995. Spatial language and spatial representation. Cognition, 55, 39-84.

Jackendoff, R. 1990. Semantic structures. Cambridge, MA: MIT Press.

Levin, B., and Rapoport, T. 1988. Lexical subordination. Papers from the 24th Regional Meeting of the Chicago Linguistics Society, 275-289. Chicago, IL: University of Chicago.

Levinson, S. 1996. Frames of reference and Molyneux's question: Crosslinguistic evidence. In P. Bloom, M. Peterson, L. Nadel and M. Garrett eds., Language and space, 109-170. Cambridge, MA: MIT Press. 
Li, P., Abarbanell, L., and Papafragou, A. 2005. Language and spatial reasoning in Tenejapan Mayans. Proceedings from the Annual Meeting of the Cognitive Science Society. Hillsdale, NJ: Erlbaum.

Li, P., and Gleitman, L. 2002. Turning the tables: Spatial language and spatial cognition. Cognition, 83, 265-294.

Newcombe, N. and Huttenlocher, J. 2003. Making space: The development of spatial representation and reasoning. Cambridge, MA: MIT Press.

Papafragou, A., Hulbert, J., and Trueswell, J. 2006. Does language guide event perception: Evidence from eye movements. Talk delivered at the Annual Meeting of the Linguistic Society of America, Albuquerque, 5-8 January.

Papafragou, A., Massey, C., and Gleitman, L. 2002. Shake, rattle, 'n' roll: the representation of motion in language and cognition. Cognition, 84, 189-219.

Papafragou, A., Massey, C., and Gleitman, L. 2006. When English proposes what Greek presupposes: The cross-linguistic encoding of motion events. Cognition, 98, B75-87.

Pederson, E., Danziger, E., Wilkins, D., Levinson, S., Kita, S. \& Senft, G. 1998. Semantic typology and spatial conceptualization. Language, 74, 557-589.

Pick, H., and Acredolo, L., eds. 1983. Spatial orientation: theory, research and application. New York: Plenum Press.

Pruden, S.M., Hirsh-Pasek, K., Maguire, M., Meyers, M., and Golinkoff, R. M., 2004. Foundations of verb learning: Infants form categories of path and manner in motion events. BUCLD 28, 461-472. Somerville, MA: Cascadilla Press.

Pulverman, R., Sootsman, J., Golinkoff, R.M., and Hirsh-Pasek, K. 2003. Infants' non-linguistic processing of motion events: One-year-old English speakers are interested in manner and path. In E. Clark ed., Proceedings of the Stanford Child Language Research Forum. Stanford: Center for the Study of Language and Information.

Quinn, P.C. 1994. The categorization of above and below spatial relations by young infants. Child Development, 65, 58-69.

Slobin, D., and Hoiting, N. 1994. Reference to movement in spoken and signed languages: Typological considerations. Proceedings of the 20th Annual Meeting of the Berkeley Linguistics Society, 487-505. Berkeley: BLS.

Stiles-Davis J., Kritchevsky, and Bellugi, U. eds. 1988. Spatial cognition: brain bases and development. Hillsdale, NJ: Erlbaum.

Talmy, L. 1985. Lexicalization patterns: Semantic structure in lexical forms. In T. Shopen ed., Language typology and syntactic description, 57-149. New York: Cambridge University Press. 